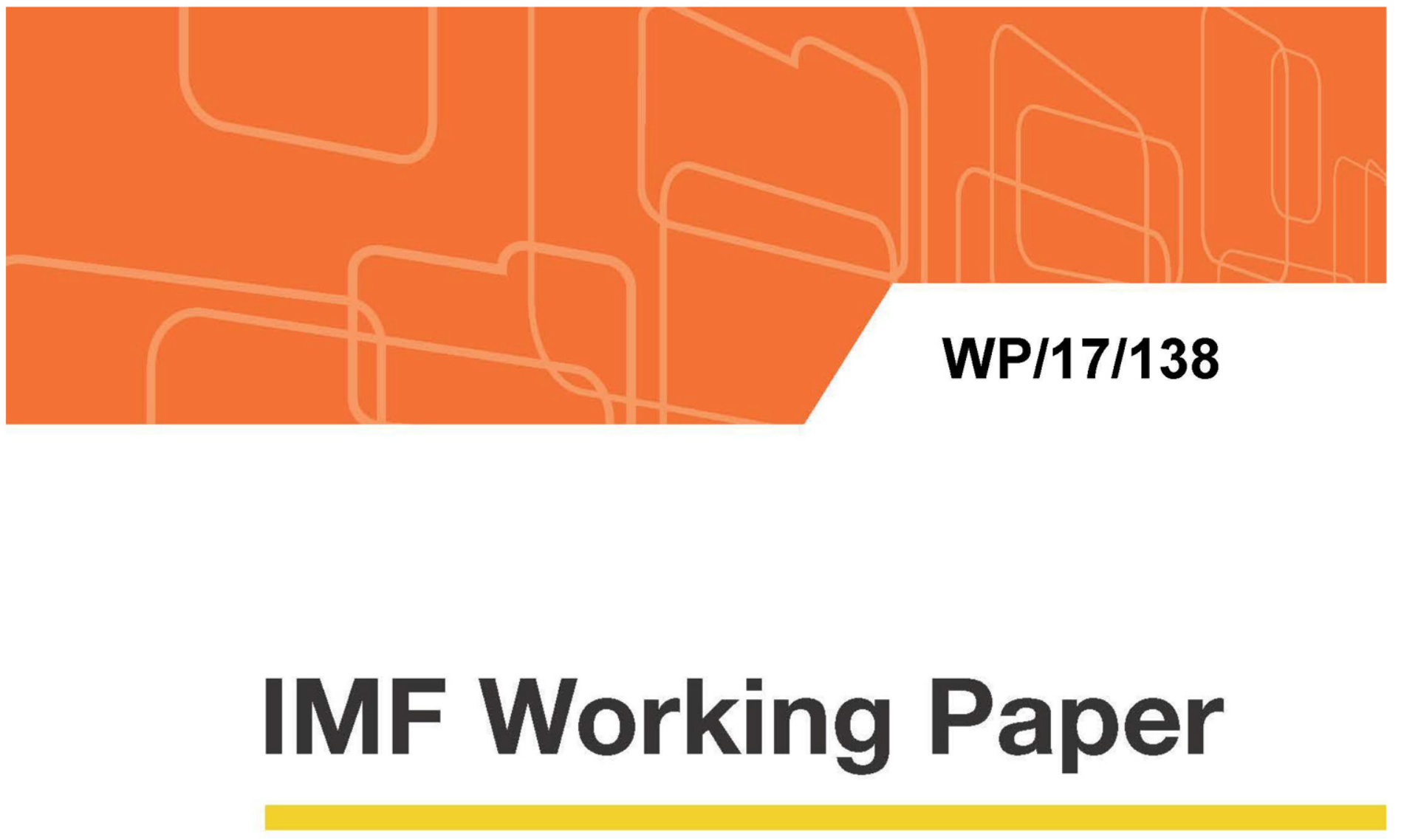

\title{
Public Investment Scaling-up and Debt Sustainability: The Case of Energy Sector Investments in the Caribbean
}

by Ahmed El-Ashram

IMF Working Papers describe research in progress by the author(s) and are published to elicit comments and to encourage debate. The views expressed in IMF Working Papers are those of the author(s) and do not necessarily represent the views of the IMF, its Executive Board, or IMF management. 


\section{WP/17/138}

\section{IMF Working Paper}

\section{Public Investment Scaling-up and Debt Sustainability: The Case of Energy Sector Investments in the Caribbean}

by Ahmed El-Ashram

IMF Working Papers describe research in progress by the author(s) and are published to elicit comments and to encourage debate. The views expressed in IMF Working Papers are those of the author(s) and do not necessarily represent the views of the IMF, its Executive Board, or IMF management.

I N T E R N A T I O N A L M O 


\title{
IMF Working Paper
}

Western Hemisphere Department

\section{Public Investment Scaling-up and Debt Sustainability: The Case of Energy Sector Investments in the Caribbean}

\author{
Prepared by Ahmed El-Ashram
}

Authorized for distribution by Trevor Alleyne

June 2017

IMF Working Papers describe research in progress by the author(s) and are published to elicit comments and to encourage debate. The views expressed in IMF Working Papers are those of the author(s) and do not necessarily represent the views of the IMF, its Executive Board, or IMF management.

\begin{abstract}
The question of how scaling up public investment could affect fiscal and debt sustainability is key for countries needing to fill infrastructure gaps and build resilience. This paper proposes a bottom-up approach to assess large public investments that are potentially selffinancing and reflect their impact in macro-fiscal projections that underpin the IMF's Debt Sustainability Analysis Framework. Using the case of energy sector investments in Caribbean countries, the paper shows how to avoid biases against good projects that pay off over long horizons and ensure that transformative investments are not sacrificed to myopic assessments of debt sustainability risks. The approach is applicable to any macro-critical investment for which user fees can cover financing costs and which has the potential to raise growth without crowding-out.
\end{abstract}

JEL Classification Numbers: H54, H63, O43, Q43

Keywords: Public Investment, Debt Sustainability, Growth, Energy Reform, Caribbean, User Fees

Author's E-Mail Address: aelashram@imf.org 


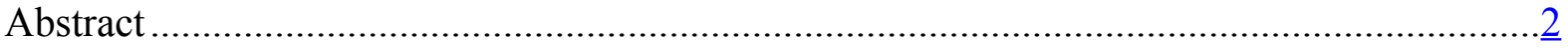

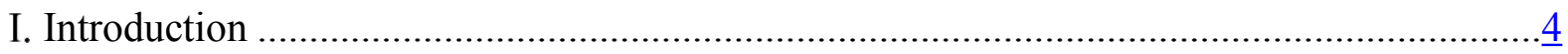

II. Public Investment and Debt Sustainability: The Value of a Bottom-up Assessment ........... $\underline{5}$

III. Macroeconomic Setting and Energy-Related Challenges in the Caribbean ....................... $\underline{8}$

IV. Sustainable Funding of Public Investments: The Case of Energy Projects in the Caribbean

A. Augmenting the DSA Framework with Public Investment Parameters .................13

B. Results of the Debt Sustainability Analysis ....................................................

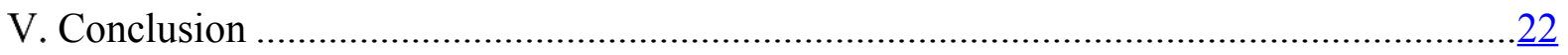

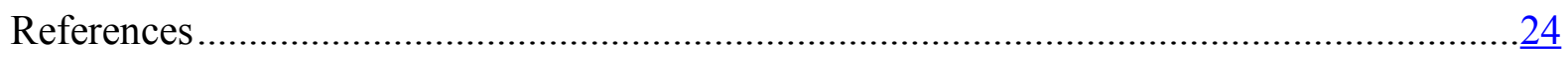

List of Tables

1. Energy Sector Investment Needs in the Caribbean (2018-2023)..................................10

2. Minimum Cost Reductions Required for Costed Energy Investments to be Self-

Financing. .$\underline{12}$

3. Potential Cost Savings from Energy Sector Investments under Alternative Scenarios for the Oil Price Outlook

\section{List of Figures}

1. Carribbean Residential Electricity Tarriffs (2002-2012) .............................................

2. Contribution of Different Parameters to the Decline in Public Debt Ratio under the Public

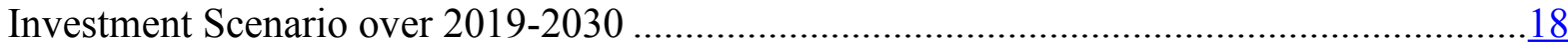

3. Impact of Energy Investments on Debt Sustainability .................................................20

4. Impact of Energy Investments on Debt Sustainability (Cont'd) ........................................

\section{Boxes}

1. Energy Efficiency and Growth

\section{Annexes}

I. Methodologies for Assessing Potential Cost Savings from Introducing Natural Gas and Renewable Energy Technologies in the Caribbean 


\section{INTRODUCTION}

1. When is scaling-up of public investment justified, to fill large infrastructure gaps? Large infrastructure investment can be transformative for growth, and be selffinancing in the long run. However, public sector borrowing to finance these investments can pose significant risks to fiscal and debt sustainability in poor or small countries where the bill is a significant share of GDP. Hence, deepening the analysis of the risk-benefit tradeoff to large infrastructure investments has become a priority for policy guidance. This is

particularly important for countries already facing challenges of low growth, high public debt and limited fiscal space.

\section{Energy sector transformation is one area where significant upfront investments} are required, often with implications for public debt and growth. The dilemma is particularly difficult for small states, where required investments are large as a share of GDP. In the Caribbean, large investments in geothermal power and natural gas technologies, estimated at about 6 percent of GDP on average, could significantly lower energy costs for the public and private sector, improving competitiveness and making investment more attractive as well as reducing pressure on external accounts, and increasing GDP over the long-run (McIntyre et al., 2016). Cost savings from shifting to some alternative energy technologies would persist even in a protracted low oil price environment, particularly for investments in natural gas facilities (see Box 1). While the pay-off is large, it would be captured only over a long period. In the meantime, high public debt and limited fiscal space, prevalent across the region, raise questions about whether these investments could be financed without jeopardizing debt sustainability. Private sector financing remains a first-best solution to this dilemma, but difficulties in securing private partners because of small market size and limited economies of scale in small states often mean an investment cannot take place without substantial public sector involvement. And even in cases where private financing is available, public-private partnerships (PPPs) often require an equity stake by the public sector, ancillary investments in related infrastructure, and, in many cases, government guarantees for the project, all with implications for public debt sustainability. ${ }^{1}$

\section{The IMF has analytical toolkits guiding policy advice on risks to debt} sustainability, but these need to draw on macro-frameworks that adequately reflect the full impact of public investment scaling up. Debt Sustainability Analysis (DSA) tools guide staff's policy advice on countries' borrowing decisions to finance their policy goals. ${ }^{2}$ However, debt sustainability analysis will bias results if it does not adequately take into account the link between public investment and the resulting growth that could make the operation self-financing (Wyplosz, 2007). To do this effectively, the macro-fiscal projections that underpin the DSA need to capture the key structural factors in an economy that will

\footnotetext{
${ }^{1}$ Private sector financing through PPPs does not preclude fiscal risks. To assess potential fiscal costs and risks from a PPP, Fund staff has developed the PPP Fiscal Risk Assessment Model (P-FRAM) (See IMF Paper "Making Public Investment More Efficient; Annex V"

${ }^{2}$ Two types of frameworks are used: one for countries with market access (MAC DSA), and the joint IMFWorld Bank Debt Sustainability Framework (DSF) tailored for LICs (IMF, 2013a and 2013b).
} 
determine the impact of an investment, including the efficiency of public investment, the return to infrastructure, and absorptive capacity (Buffie et al., 2012).

4. This paper proposes a selective bottom-up approach, based on project-level analysis, to assess debt sustainability risks when large investment projects with potentially large macro-payoff are under consideration. The approach is bottom-up since it takes stock of the macro-fiscal impact of individual investment projects deemed macrocritical - a technique most likely to be justifiable in small states where such large investments are few and represent a significant share of GDP. The paper examines the case of power sector investments in a sample of Caribbean countries and uses three key public investment parameters (the growth impact of the investment, the resulting impact on the public sector primary balance, and the projected cost of financing) to reflect the impact of the investments on the macro-fiscal projections used for debt sustainability analysis. Including these additional factors in macro-projections would enhance the results of the DSA and avoid biases against good projects that pay off only over long horizons. The approach is potentially applicable to any macro-critical investment that can achieve significant cost savings or revenues from user fees to cover its cost of financing.

5. The findings of this paper support the view that efficient public investments in energy may improve public debt sustainability through favorable growth spillovers, as long as the baseline debt trajectory is sustainable. Augmenting the macro-framework with the impact of proposed energy investments on debt service, public sector primary balance, and long-run growth yields debt trajectories that are more favorable than the baseline over the long run. The analysis also suggests that private financing of energy investments would significantly improve public debt over the long run through the potential growth-enhancing impact, provided that a significant share of the cost savings is passed on to end-users, say, in the form a lower electricity tariff. The paper concludes with a range of caveats (some already in the literature on scaling up public investments) about the conditions necessary for scalingup to be compatible with safeguarding fiscal and debt sustainability and macroeconomic stability.

\section{Public Investment and Debt Sustainability: The Value of A Bottom-UP Assessment}

6. Macro-frameworks that underpin the Debt Sustainability Analysis need to be enhanced to reflect adequately the link between public investment and growth. A longer-term and broader macro-framework, fully reflecting the impact of public financing of macro-critical investment projects, will typically be more appropriate for countries in a high debt-low growth trap. Because the bulk of such projects require front-loaded financing, the short-term impact on the debt-to-GDP ratio is typically unfavorable. A full analysis should balance short-term costs against expected medium and long-run growth dividends and potential cost savings, including to the public sector, to avoid delivering policy advice that sacrifices potentially high-yielding projects to near-term debt sustainability concerns. Moreover, the DSA should ideally be based on the broadest fiscal perimeter for the public 
sector. ${ }^{3}$ This covers the primary balance of state-owned enterprises, including capital spending and additional revenue streams from new investments, and their debt service. Comprehensive coverage of potential revenue and expenditure streams (as well as contingent liabilities) from public investment projects, including those undertaken by state-owned enterprises, would strengthen the quality of the primary balance projections that govern the debt dynamics.

7. Ideally, these dynamics would be best captured via a comprehensive general equilibrium macroeconomic model. One such example is Buffie et al's (2012) DebtInvestment-Growth (DIG) model, which has been used successfully for modeling the impact of public investment in low-income and emerging economies with large infrastructure gaps and significant development needs. ${ }^{4}$ The DIG explicitly analyzes inter-linkages between public investment, growth and public debt under different financing scenarios and economic circumstances. ${ }^{5}$ Buffie et al's approach, like the one in this paper, is motivated by the dilemma where large infrastructure investments may be self-financing in the long run, but pose risks to fiscal and debt sustainability over the near and medium term, depending on structural conditions, delays in capturing fiscal revenue gains from growth, and the type of available financing. Buffie et al particularly emphasize the challenge of transition problems - fiscal pressures in the years before benefits from investment for growth and fiscal revenues materialize - and the importance of concessional financing for public investment to avoid such problems.

\section{The DIG general-equilibrium model has been applied for several countries to highlight the debt-growth tradeoff of development plans. However, the DIG may be} limiting when attempting to capture a complex policy mix. It requires a wide range of specifications for a large system of equations, and, for simplification, restricts fiscal policy tools to changes in the consumption tax rate and transfers. This makes it difficult to analyze a single big proposed investment while taking into account the complex fiscal options often faced by countries in transition or in fiscal adjustment programs. ${ }^{6,7}$ The model is also highly dependent on macro-parameters such as public investment efficiency and marginal productivity of capital, which are usually difficult to estimate for a less developed economy. ${ }^{8}$

\footnotetext{
${ }^{3}$ Because the DSA models overall public debt, including debt by state-owned enterprises, the debt dynamics equation should reflect the public sector primary balance, rather than the central or general government balance.

${ }^{4}$ The DIG has also been customized by turning off some its LIC specific features, to allow for its applications to emerging economies.

${ }^{5}$ The DIGNAR (Debt, Investment, Growth and Natural Resources) variant of this model has been developed by Melina, Yang and Zanna (2014) for the effect of scaling up public investment in resource-abundant developing countries.

${ }^{6}$ The DIGNAR variant for natural resource exporters does introduce labor income and capital taxes as two additional policy instruments in addition to a resource fund.

${ }^{7}$ More recently, a user-friendly web-based version of the DIG has been launched to promote its application.

${ }^{8}$ Recent work by Fund staff has enhanced the measurement of public investment efficiency in a sample of middle and low income countries (see Dabla-Norris et al., 2011). In addition, a new cross-country Public
}

(continued...) 
Further enhancements to the DIG are also needed to model exchange rate and financial sector dynamics in economies with abundant savings and surplus liquidity. ${ }^{9}$

\section{A bottom-up assessment of large-scale public investment projects can provide}

more specific guidance. The benefits of focusing on project-level analysis are three-fold:

i) the impact of an investment on growth can be more accurately calibrated if the analysis uses sector-specific parameters, rather than relying on economy-wide estimates of the marginal productivity of capital. In the case of energy investments, this means estimating the direct growth impact of reducing energy costs;

ii) the analysis can more accurately estimate the fiscal impact, including fiscal savings expected from investments which generate measurable cost reductions or significant returns from user fees;

iii) the approach retains considerable flexibility in formulating the macro-fiscal projections that underpin the DSA, making it easier to use in countries contemplating growth-enhancing investments while undertaking complex fiscal consolidation programs.

10. A bottom-up assessment can more easily identify sources of fiscal risks from scaling-up public investment. By focusing on project-specific parameters, a credible bottom-up assessment reduces the risk of undertaking economically unviable or white elephant projects, including by estimating the project's net payoff and identifying risks to its materialization. In the case of energy projects, poor financial performance of the power utility, or improper incentives that stop tariff rates short of achieving full cost-recovery, could increase fiscal risks and weaken the financial position of the power utility and, ultimately, the budget. Also, low collection of user fees due to poor governance and/or political limitations would mean that the project's cash flow could not be guaranteed, with implications for the public sector primary balance. These risks come on top of other typical red flags against scaling-up public investment: low public investment efficiency, low return on public capital, and weak public financial management practices - each of which could negate any favorable impact of public investment on debt dynamics.

Investment Efficiency Index (PIE-X) has been recently developed by the IMF and described in a recent Board paper (IMF, 2015).

${ }^{9}$ One of the key findings of Buffie et al. (2012) is that domestic borrowing by the public sector to finance public investment projects will unequivocally lead to crowding out of the private sector and a reduction in private investment and consumption. This may not be true in economies with significant surplus liquidity in the domestic banking sector, as in several Caribbean economies.

(continued...) 


\section{Macroeconomic SetTing AND Energy-Related Challenges IN THE CARIBBEAN}

\section{Low growth and high public debt have plagued most of the Caribbean region} over the past decade. ${ }^{10}$ Real GDP growth declined to an average of 1.8 percent over 20062015 , down from 3.3 percent over the previous decade. This reflects a slow recovery following the global financial crisis, particularly in tourism-based economies which, in part, is explained by competitiveness gaps related to the Caribbean's high costs, including the cost of energy. ${ }^{11}$ Meanwhile, the region suffers from a significant public debt burden of about 82 percent of GDP with acute fiscal vulnerabilities in some countries. Commodity exporters Belize, Guyana, Suriname, and Trinidad \&Tobago fared better on the back of the commodity price boom since 2010, with relatively lower public debt at around 60 percent of GDP, but average growth rates remain lower than in the previous decade, and the recent commodityprice decline has dampened growth and raised fiscal pressures.

\section{Macroeconomic challenges have been aggravated by the region's}

overdependence on expensive petroleum products. Imported fuel oil represents about

90 percent of total primary energy

consumption in the Caribbean and

exposing the region to episodes of high

and volatile oil prices and prohibitively

high electricity tariffs. Average

electricity tariffs in the region increased by almost 80 percent over 2002-2014, to reach an average of $0.35 \mathrm{US} \$ \mathrm{kWh}$ in 2014 , more than three times the cost of electricity in the US and one of the highest in the world. Oil price shocks were also found to have negatively affected growth, filtered into domestic

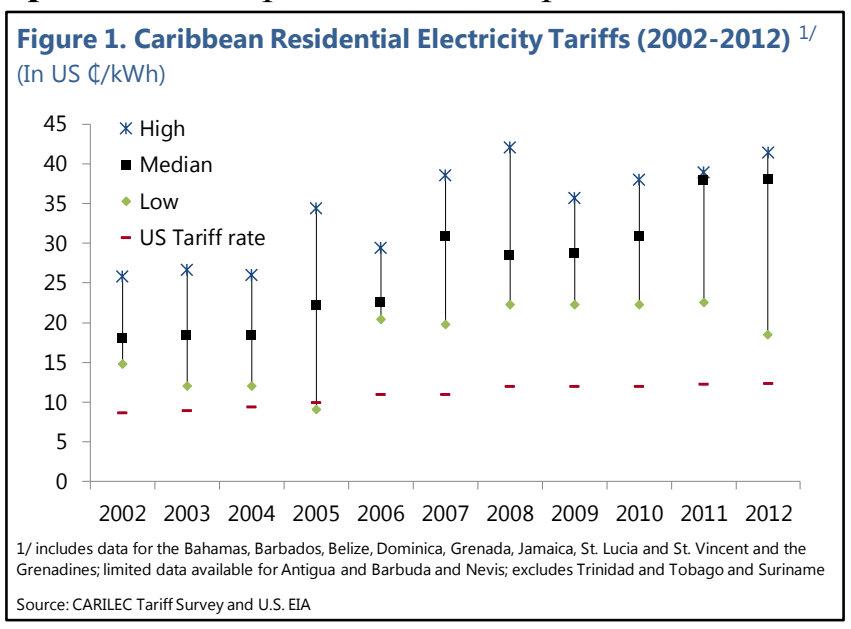
inflation, and contributed to increasing the rate of real exchange rate appreciation across the region (McIntyre et al., 2016). Outdated power systems and under-maintained power grids with high system losses have also increased energy sector costs.

13. Energy challenges have also increased the region's external imbalances. The region's current account deficit averaged about 14 percent of GDP over the past decade, of which the oil deficit was, on average, about 7 percent of GDP. This was financed partly through the PetroCaribe Energy Agreement with Venezuela, which provided concessional financing over 20-25 years for 40 to 60 percent of oil purchases by participating Caribbean countries, depending on the oil price and individual country agreements. Since the oil price decline in 2015, external financing through PetroCaribe has diminished, but the region

\footnotetext{
${ }^{10}$ Refers to the Bahamas, Barbados, Belize, Guyana, Jamaica, and the six independent states of the Eastern Caribbean Currency Union; does not cover Trinidad and Tobago, the sole net energy exporter in the Caribbean.

${ }^{11}$ World Bank Doing Business Indicators have shown a decline in the competitiveness of several Caribbean economies since the global financial crisis, reflecting a range of factors, including elevated cost of doing business, resolving insolvency, access to affordable credit and electricity, among others.
} 
remains exposed to risk of a sudden stop in case of a complete disruption in the arrangement, with significant implications for fiscal and external sustainability.

\section{Effective energy sector reform could have a substantial macroeconomic impact} by lowering tariffs and reducing national oil bills. McIntyre et al. (2016) analyze the impact of achieving renewable energy and energy efficiency targets announced in Caribbean national and regional energy strategies. ${ }^{12}$ They show that implementing these targets could reduce fuel oil import costs and generate significant cost savings in the national energy bill. Their paper also models the impact of improving energy efficiency on economic output, including through diversifying into more cost-efficient renewable energy and natural gas technologies. The long-run elasticity of GDP to energy efficiency is estimated at 0.2 in the Caribbean (see Box 1). This implies an increase of 2 percent in the level of GDP over the long run, for every 10 percent improvement in energy efficiency.

\section{Box 1. Energy Efficiency and Growth}

McIntyre et al. (2016) examined the role of energy sector reform in addressing Caribbean vulnerabilities and improving growth and competitiveness. ${ }^{1}$ It evaluated existing national and regional energy strategies, including their affordability and the expected gains from their implementation. To estimate the gains, the authors undertook a series of empirical tests to assess the impact of lower energy costs on economic activity and competitiveness indicators like the real effective exchange rate (REER), both in the short and long run. Their analysis suggested the following.

In the short run, a reduction in energy costs (a lower oil bill) will have a noticeable impact on real GDP growth and changes in REER in the Caribbean. A country-specific vector autoregressive (VAR) model with block exogeneity restrictions using annual data over 1976-2013, suggested the following:

- Changes in real oil prices explain on average about 7\% of variation in real GDP growth.

- A $10 \%$ decline in real oil prices increases real GDP growth by about $\mathbf{0 . 5}$ pp over 5 years in tourism-intensive countries.

- A $10 \%$ decline in real oil prices lowers the rate of REER appreciation by $\mathbf{2 . 8}$ pp over 5 years in tourism-intensive countries and $\mathbf{3 . 8} \mathbf{p p}$ in commodity-producers.

Over the long run, reducing high energy costs through improving energy efficiency would have a discernible impact on long-run economic activity. The authors estimated the GDP elasticity to energy consumption (per capita), capital formation (per capita), and a parameter for energy efficiency, in a panel co-integration approach using the Augmented Mean Group estimator (AMG). ${ }^{2}$ The model suggested that energy consumption and efficiency as well as gross capital formation play a significant role in determining the level of GDP in the Caribbean over the long run. In particular, a 1 percent improvement in energy efficiency would leave GDP 0.2 percent higher over the long-run. These results implied that investing in energy-efficient technologies, including efficient renewable and natural gas power plants, would have a direct impact on economic activity and generate growth dividends that could make the initial investments economically self-financing. Based on these results, we assigned a GDP-to-energy efficiency elasticity of 0.2 in augmenting the GDP growth rate in the macro-framework, based on the magnitude of cost savings from the new energy-efficient facilities (see $\mid 22$ and $\uparrow 23$ ).

1/ The paper excluded Haiti and focused on energy importers.

2/ The empirical exercise for assessing long-term effects of energy consumption and energy efficiency on growth relied on Pesaran, Shin and Smith (1998), Giraud and Kahraman (2014), and Stern and Kander (2012). See McIntyre et al. (2016),

Annex I.

\footnotetext{
${ }^{12}$ Refers to renewable and energy efficiency targets identified in the Caribbean Sustainable Energy Roadmap and Strategy (2015).
} 


\section{Energy sector transformation would, however, require large upfront} investments to make necessary upgrades and introduce energy-efficient technologies. The Inter-American Development Bank (IDB) estimates that total energy sector investment requirements in the Caribbean amount to about 6 percent of regional GDP in 2015 (see Table 1). This envelope covers both investments to upgrade existing power plants to improve generation efficiency and reduce system losses, and to introduce alternative energy sources like natural gas, geothermal, solar, and wind in countries where these technologies are viable.

\begin{tabular}{|c|c|c|c|c|c|c|c|}
\hline \multicolumn{8}{|c|}{$\begin{array}{l}\text { Table 1. Energy Sector Investment Needs in th } \\
\text { (in millions of USD) }\end{array}$} \\
\hline & $\begin{array}{l}\text { Building/ } \\
\text { Upgrading } \\
\text { power } \\
\text { plants }^{1 /}\end{array}$ & $\begin{array}{l}\text { Introducing } \\
\text { Natural Gas } \\
\text { Facilities }^{2 /}\end{array}$ & $\begin{array}{l}\text { Renewable } \\
\text { Energy } \\
\text { Investments } \\
3 / 4 /\end{array}$ & $\begin{array}{c}\text { Total } \\
\text { Investment }\end{array}$ & $\begin{array}{c}\text { Total } \\
\text { Investment } \\
(\% G D P)^{6 /}\end{array}$ & $\begin{array}{l}\text { Average } \\
\text { GDP } \\
\text { Growth } \\
(2006-2015)\end{array}$ & $\begin{array}{c}\text { Gross } \\
\text { Public Debt } \\
\text { (\% of GDP) } \\
6 /\end{array}$ \\
\hline The Bahamas & 150 & 251 & 70 & 471 & 5.3 & 0.4 & 60.8 \\
\hline Barbados & 190 & 129 & 80 & 399 & 9.0 & 0.6 & 103.8 \\
\hline Belize & & 59 & - & 59 & 3.3 & 2.6 & 78.1 \\
\hline Guyana & 135 & 110 & 5 & 250 & 7.8 & 4.4 & 70.2 \\
\hline Jamaica & 400 & 280 & 60 & 740 & 5.4 & 0.1 & 127.7 \\
\hline Suriname & 100 & 223 & 45 & 368 & 7.3 & 3.8 & 36.9 \\
\hline ECCU & & & 421 & 421 & 9.2 & 1.2 & 82.9 \\
\hline Antigua \& Barbuda & & & 42 & 42 & 3.3 & 1.2 & 101.9 \\
\hline Dominica & & & 52 & 52 & 9.7 & 2.4 & 79.4 \\
\hline Grenada & & & 88 & 88 & 9.1 & 0.7 & 90.3 \\
\hline St. Kitts and Nevis & & & 87 & 87 & 9.7 & 2.0 & 66.3 \\
\hline St. Lucia & & & 66 & 66 & 4.6 & 1.1 & 82.6 \\
\hline St. Vincent \& Gr. & & & 87 & 87 & 11.4 & 1.0 & 77.0 \\
\hline Region Total & 975 & 1,052 & 681 & 2708 & 6.3 & 1.9 & 80.0 \\
\hline \multicolumn{8}{|c|}{$\begin{array}{l}\text { Source: IDB and IMF staff estimates. } \\
\text { 1/ Includes cost of building new capacity of natural gas-fired power plants. IDB estimates do not include expansions for } \\
\text { generation capacity in Belize, which imports a significant share of its electric power from Mexico. For Guyana and Suriname } \\
\text { includes costs for rural electrification. } \\
\text { 2/ Includes estimated costs of converting existing plants to natural gas and the construction of regasification facilities. } \\
\text { 3/ Includes solar, hydro, wind, and waste-to-energy projects. For the ECCU, reflects cost for geothermal power development. } \\
\text { 4/ For Antigua and Barbuda, reflects cost estimates for solar and wind power peneration of } 20 \text { percent by } 2020 \text {. } \\
\text { 5/ Includes cost for solar water heaters, grid loss reduction, street lighting retrofit and smart fund for EE projects. } \\
\text { 6/ Based on } 2015 \text { estimates }\end{array}$} \\
\hline
\end{tabular}

16. Such large investments, if publicly financed, could have significant implications for debt sustainability in some countries, raising questions about when they would or would not be justified. For countries with solid public finances, an additional investment envelope in the order of 6 percent of GDP could be financeable by the public sector, without undermining debt sustainability. However, in several Caribbean countries, public finances remain under strain, constraining possibilities for undertaking large energy infrastructure investment. An analysis of the impact of estimated energy investment costs on public debt sustainability in selected Caribbean countries is outlined next. 


\section{Sustainable Funding of Public Investments: The Case of Energy Projects IN THE CARIBBEAN}

17. Public investment projects can be effectively self-financing when they can charge a user fee, provided that they are well planned and executed. Because user fees generate a revenue stream, some public investment projects can cover their cost of financing and/or provide for additional fiscal savings. Energy investments in the Caribbean are one such case, where reductions in power generation costs from introducing alternative energy sources can potentially allow power utilities to cover their cost of financing through tariff collection while still reducing energy costs for the wider economy. All energy investment plans costed by the Inter-American Development Bank (IDB) shown in Table 1 target technologies that can generate cost savings for both power utilities and commercial users. Table 2 shows the minimum cost reductions required for the proposed investment envelope for each country to be economically viable under different cost-recovery scenarios ranging from 15 to 25 years in both US\$ cents per $\mathrm{kWh}$ and in percent of the average operating expense of the relevant power utilities estimated over 2012-2015. Transformational projects that significantly enhance economic productivity while collecting a user fee, including investments in telecoms, and toll road and bridge networks as well as other mega projects, like the expansion of the Panama Canal, are examples of macro-critical public investments that could generate a significant revenue stream while enhancing long-run potential growth.

18. Absent user fees, some public investment projects could still prove self-financing if they generate substantial cost savings to the government. Investments in disasterresilient infrastructure projects are one such example. Although these infrastructure investments may not generate a distinct revenue stream, they would result in significant fiscal savings in disaster-prone countries by reducing the cost of a natural disaster and its impact on public finances, including on tax revenues and spending on disaster relief and reconstruction. In the Caribbean and Pacific Island Countries, where the probability of a natural disaster averages about 20 percent in a given year, ${ }^{13}$ such investments would directly improve public debt sustainability compared to a baseline that incorporates such risks, both by limiting the deterioration of the public sector primary balance and preserving the productive capacity of the economy, in the aftermath of large natural disaster shocks.

\section{Backing public investments with user fees where possible can reduce the risk of} transition problems. Buffie et al. (2012) cautioned that the transition path of public investment scaling-up can involve difficult fiscal adjustment if revenue gains (improved tax collections from growth) do not materialize soon enough, with adverse consequences for private investment and consumption. The solution advocated by the authors, to rely on concessional financing, is often not feasible in middle and upper-income countries, including in the Caribbean, which still face infrastructure gaps or require new investments to raise potential growth. The alternative of privileging, where possible, projects with revenue streams from user fees that sufficiently cover the cost of financing spread over the useable life of the project, would reduce the risk of fiscal shortfalls and avoid distortionary fiscal

\footnotetext{
${ }^{13}$ See IMF Working Paper 15/125: "Enhancing Macroeconomic Resilience to Natural Disasters and Climate Change in the Small States of the Pacific."
} 
adjustment to address them. Although the investment itself could be front-loaded, the project's future cash flow can be sufficient to service related debt and ease financing risks to government. However, this cash flow stream may need to be risk-adjusted to reduce risks of financing shortfalls to the government, if returns are less than projected. Table 3 includes returns under different risk scenarios for the oil price. ${ }^{14}$

\begin{tabular}{|c|c|c|c|c|c|c|c|c|c|c|}
\hline & \multirow{3}{*}{$\begin{array}{l}\text { Estimated } \\
\text { Net } \\
\text { generation } \\
\text { (2015) } \\
\text { (in GWH) }\end{array}$} & \multirow{3}{*}{$\begin{array}{l}\text { Estimated } \\
\text { Avg. } \\
\text { Operating } \\
\text { Expense } \\
(2012-2015)^{1 /}\end{array}$} & \multicolumn{2}{|c|}{ US\$ Million } & \multicolumn{6}{|c|}{ Minimum Cost Reductions } \\
\hline & & & \multirow[t]{2}{*}{$\begin{array}{c}\text { Total } \\
\text { investment } \\
\text { cost }\end{array}$} & \multirow{2}{*}{$\begin{array}{l}\text { Projected } \\
\text { annual cost } \\
\text { of debt } \\
\text { service }^{2 /}\end{array}$} & \multicolumn{3}{|c|}{ (In US cents/kWh generated) } & \multicolumn{3}{|c|}{$\begin{array}{l}\text { (In percent of Avg. Operating } \\
\text { Expense of the Utility) }\end{array}$} \\
\hline & & & & & 15 Years & 20 Years & 25 Years & 15 Years & 20 Years & 25 Years \\
\hline The Bahamas ${ }^{3 /}$ & 1952 & 26 & 511 & 39.0 & 2.2 & 2.0 & 1.9 & 8.3 & 7.7 & 7.1 \\
\hline Barbados & 1036 & 25 & 439 & 33.5 & 3.5 & 3.2 & 3.0 & 13.9 & 12.9 & 12.0 \\
\hline Belize & 449 & 18 & 59 & 4.5 & 1.1 & 1.0 & 0.9 & 6.1 & 5.7 & 5.3 \\
\hline Guyana & 881 & 21 & 270 & 20.6 & 2.5 & 2.3 & 2.2 & 11.9 & 11.0 & 10.2 \\
\hline Jamaica & 4213 & 29 & 860 & 65.6 & 1.7 & 1.6 & 1.4 & 5.8 & 5.4 & 5.0 \\
\hline Suriname & 1857 & 19 & 378 & 28.8 & 1.7 & 1.6 & 1.4 & 8.7 & 8.1 & 7.5 \\
\hline Antigua \& Barbuda & 325 & 26 & 47 & 3.6 & 1.2 & 1.1 & 1.0 & 4.6 & 4.2 & 3.9 \\
\hline Dominica & 99 & 28 & 57 & 4.3 & 4.7 & 4.4 & 4.1 & 17.1 & 15.8 & 14.7 \\
\hline Grenada & 199 & 30 & 93 & 7.1 & 3.8 & 3.5 & 3.3 & 12.7 & 11.7 & 10.9 \\
\hline St. Kitts and Nevis & 144 & 26 & 92 & 7.0 & 5.2 & 4.8 & 4.5 & 20.1 & 18.5 & 17.3 \\
\hline St. Lucia & 373 & 24 & 71 & 5.4 & 1.6 & 1.5 & 1.4 & 6.5 & 6.0 & 5.6 \\
\hline St. Vincent \& Gr. & 141 & 26 & 92 & 7.0 & 5.4 & 5.0 & 4.6 & 20.5 & 19.0 & 17.7 \\
\hline Average & 972 & 25 & 247 & 18.9 & 2.9 & 2.7 & 2.5 & 11.4 & 10.5 & 9.8 \\
\hline \multicolumn{11}{|c|}{$\begin{array}{l}\text { 1/ Estimated from financial statements of power utilities and Castalia reports. Where data was not available, the weighted average cost of } \\
\text { generation was used in addition to an average non-fuel operating expense of US } \$ 0.07 / \mathrm{kWh} \text { based on data from BPL and JPS. } \\
\text { 2/ Reflects a base case of } 20 \text { year amortization schedule for a loan with a } 5 \text { percent interest rate and varies for different loan-maturities. } \\
\text { 3/ Operating expense is estimated for BEC. } \\
\text { Sources: US. EIA, Castalia Energy Monographs, IDB, Power Utilities' Annual Reports and IMF Staff Estimates. }\end{array}$} \\
\hline
\end{tabular}

\section{The impact of scaling-up investment will also depend on domestic financial}

conditions. Domestic financing of public investment is less likely to crowd out private consumption and investment if the domestic banking system has significant surplus liquidity that can be mobilized through long-term financing instruments. In the Caribbean, limited private sector investment opportunities and banks' high risk aversion has hampered bank lending (in the face of elevated NPLs and low capital adequacy ratios), leading to a build-up of surplus liquidity and low bank profitability in several countries. Meanwhile, the high public debt load of most countries has dampened banks' appetite for increasing their exposure to government debt. Mobilizing this domestic liquidity by issuing infrastructure bonds or long-term loans to finance public investment projects which are directly serviced through the project's proceeds, can overcome this intermediation bottleneck and ensure a sustainable cost of finance. However, an appropriate legal and regulatory framework is needed, often with credit guarantees from multilateral agencies to enhance the appeal of holding financing instruments of very long maturities.

\section{In the absence of sufficiently deep capital markets, long-term external funding from development agencies is likely to be the best option for financing large-scale}

\footnotetext{
${ }^{14}$ Also, the stream of cash flows could be discounted with an appropriate risk-adjusted discount rate and the net present value compared with initial cost of financing.
} 
projects. Matching the terms of financing with the project's yield is critical to debt sustainability. Funding long-term development projects through short-term debt instruments or long-term instruments with floating interest rates is likely to aggravate debt sustainability risks and increase public sector financing pressure in the event of unexpected shocks-such as the higher global interest rates currently anticipated. In this exercise, a 20 -year projectbased loan with a 3-year grace period from the Inter-American Development Bank is used as a base-case for financing energy projects in all 12 Caribbean countries (see 928 ). Funding projects through foreign commercial institutions or international financial markets would probably increase debt service costs and reduce cost savings beyond what is modeled. It would also increase public sector vulnerability to unexpected global shocks.

\section{A. Augmenting Macro-fiscal Projections with Public Investment Parameters}

\section{Growth projections need to reflect the impact of high-yielding public} investments on GDP growth under credible financing scenarios. In this exercise, real growth projections of 12 Caribbean countries were augmented to account for two distinct impacts: i) a short-run impact on growth through the direct expansion of aggregate demand; and ii) a favorable impact on long-run GDP as a result of lower energy costs from improvements in energy efficiency. The former was proxied by a historically estimated public investment multiplier (about 0.37 after 4 quarters in the case of the Caribbean), ${ }^{15}$ while the latter was modeled by examining the elasticity of long-run GDP to changes in energy efficiency in the economy. ${ }^{16}$ To the extent that energy investments improve growth, pressures on debt sustainability from financing them would abate. Conversely, the debt path would worsen in the face of factors dampening the growth impact of the investment, including lower efficiency gains from new technologies, lower oil prices (compared to baseline assumptions) and higher financing costs.

\section{For energy investments, efficiency gains are expected to translate to long-run} growth benefits by generating sustained reductions in the economy's aggregate energy bill. This would improve business competitiveness, increase households' ex-energy discretionary income and reduce external imbalances. The magnitude of growth dividends will depend on the level of cost savings re-injected into the economy. In this exercise, the power utility (whether public or privately owned) retains about 40 to 50 percent of cost savings, net of the cost of project financing as a return on investment, while the rest is passed on to end-users in the form of lower electricity tariffs. ${ }^{17}$ Because of the larger cost savings from introducing natural gas technologies, end-users are expected to benefit from more

\footnotetext{
15 See IMF Working Paper 13/117: "Fiscal Multipliers in the ECCU".

${ }^{16}$ Applying McIntyre's elasticity of real GDP to energy efficiency (see Box 1) generates a 2 percent increase in the level of real GDP after 10 years following a 10 percent improvement in energy efficiency across the economy.

${ }^{17}$ A scenario where all cost savings are retained by the utility would imply higher public sector primary balances and no reduction in the energy bill of the broader economy, hence no growth enhancing impact.
}

(continued...) 
reductions in their energy bills compared to other technologies, like geothermal in the ECCU, under the baseline scenario for oil and natural gas prices (See Table 3). ${ }^{18}$

\section{Estimates of efficiency gains were derived based on the underlying energy} technology being introduced (see Annex I). Returns on introducing geothermal power were investigated in the Eastern Caribbean, which has significant geothermal resources, while returns from introducing natural gas technologies were examined in the rest of the Caribbean, where larger market size allows the technology to be economically viable. Both technologies were assessed for their ability to reduce average cost of electricity generation compared to distillate fuel over a 20-year horizon (2019-2038), while accounting for expansion in demand for energy and projections of fuel prices over the forecast horizon.

25. In smaller economies, larger cost reductions are needed for the same project to be self-financing. Economies of scale lower the threshold for projects to be economically viable. In Jamaica, cost reductions of about only $1 \frac{1}{2} \mathrm{US}$ cents/kWh are needed to finance natural gas facilities costing more than US\$ 850 million, while, in Barbados, savings in excess of 3 US cents/kWh are needed for facilities costing about US\$440 million, mainly because of smaller market size. Likewise, ECCU states face higher thresholds for introducing geothermal power, largely because of their smaller population and energy consumption.

26. The returns on investment from user fees or cost savings imply a higher public sector primary balance that has a significant impact on debt dynamics. The higher primary balance would cover the cost of debt service, allowing the debt ratio to decline as the debt is amortized, and, in the case of public sector utilities, the primary balance would include any additional savings retained by power utilities as a return on investment. Additionally, if the public sector consumes a large share of the energy bill, lower electricity tariffs may generate additional fiscal savings.

27. The public debt trajectory will thus be governed by the debt dynamics equation augmented by the impact of public investments on debt service costs, growth and the public sector primary balance.

$$
d_{t}=\frac{\left(1-\alpha_{t-1}\right)\left(1+i^{d}\right)+\alpha_{t-1}\left(1+i^{e}\right)}{\left(1+\theta_{t}\right)(1+\delta)\left(1+g_{t}\right)\left(1+\pi_{t}\right)} d_{t-1}-\left(p b_{t}+\lambda \mu_{t}\right)+\varepsilon_{t}
$$

Where $d$ denotes public sector debt; $i^{d}$ is the weighted average nominal interest rate on the debt stock excluding the project loan; $i^{e}$ is the interest rate on the energy loan; $\alpha$ is the share of the energy loan in the public debt portfolio; $\theta$ reflects the impact of the investment

\footnotetext{
${ }^{18}$ In the ECCU, where geothermal is the more viable alternative energy source, cost savings are expected to average 19 percent, half of which are expected to be passed on to end-users. Under a higher oil price scenario, larger cost savings would allow a larger pass-through to end-users.
}

(continued...) 
in the energy sector on GDP growth in period t; ${ }^{19} \delta$ reflects the impact of higher energy efficiency on GDP growth over the long run; $\pi$ is the inflation rate; $p b$ is the public sector primary balance; $\mu$ is the recouped cost savings to cover the energy loan debt service; ${ }^{20} \lambda$ is the share of the public sector in financing the energy investment; and $\varepsilon$ denotes other debtrelated flows. $^{21}$

\section{In this exercise, average cost savings from planned energy investments and} related debt service are calculated through 2038. Cost savings are calculated for each country under a baseline scenario for oil and gas prices over 2019-2038, consistent with a 20year cost-recovery schedule. ${ }^{22}$ This reveals significant gains in operational efficiency (see Table 3). Debt service costs are calibrated for a 20-year commercial loan, disbursed over three years (2016-2018), with a 3-year grace period and an average interest rate of 5 percent (consistent with the projected cost of potential multilateral funding to the region through 2019). ${ }^{23}$ Table 3 shows potential cost reductions, net of debt service, in US $\$$ cents/ $\mathrm{kWh}$ and in percent of estimated average operating expense for the different power utilities in the region.

- The largest cost savings accrue to countries where the introduction of natural gas is viable. These average about 35 percent of utilities' recent operating costs under baseline projections for the prices of natural gas and distillate fuel oil by the U.S. Energy Information Agency. ${ }^{24}$

- Countries where hydroelectric power capacity is significant, such as Belize and Suriname, have overall lower energy costs.

- Compared to geothermal power, natural gas provides larger savings partly because the introduction of natural gas allows not only future but also currently-installed generation

\footnotetext{
${ }^{19}$ The parameter $\theta$ boosts growth in periods $(\mathrm{t})$ when the investment takes place, depending on the size of the investment the takes place. In this exercise, the investment is equally divided over three years of project implementation.

${ }^{20}$ In the case of investments that do no generate a distinct revenue stream but provide for significant cost savings, like disaster-resilient infrastructure investments, $\mu$ would reflect the improvement in the public sector primary balance compared to a baseline scenario that incorporates the cost of natural disasters.

${ }^{21}$ Under the private sector financing scenario, $\lambda$ is 0.2 reflecting the share of the public sector in the energy investment and its recouped cost savings. Under the public sector financing scenario, $\lambda$ is equal to 1 .

${ }^{22}$ See Table 3. The US EIA projects the average price of oil over 2019-2038 to be US\$101/Bbl, with the average price of natural gas being US\$4.8/MMBTU over the same period.

23 The interest rate assumption is calibrated for a potential IDB Investment loan. The IDB charges a floating interest rate on its loans with a 3-month LIBOR as a base rate plus a varying spread (1.15 percent as of 2015Q4). However, the base rate can be fixed after each disbursement (a 20-year loan fully disbursed as of endNovember 2015 would have a fixed interest rate of 2.55 percent). The assumed 5 percent rate implies an increase in interest rates by 2.5 percent over the horizon of the disbursements. This is consistent with the average of projections for the Federal Funds Rate over 2016-2018 (2.5 percent vs. a current 0.1 percent) by Federal Reserve Board Members released in the September 2015 FOMC meeting minutes.

${ }^{24}$ Cost savings are calculated in percent of historical average operating expense over (2012-2015).
} 
capacities to be run by natural gas. This maximizes the return on related investment, particularly if demand for energy is projected to grow significantly over the forecast horizon..$^{25,26}$

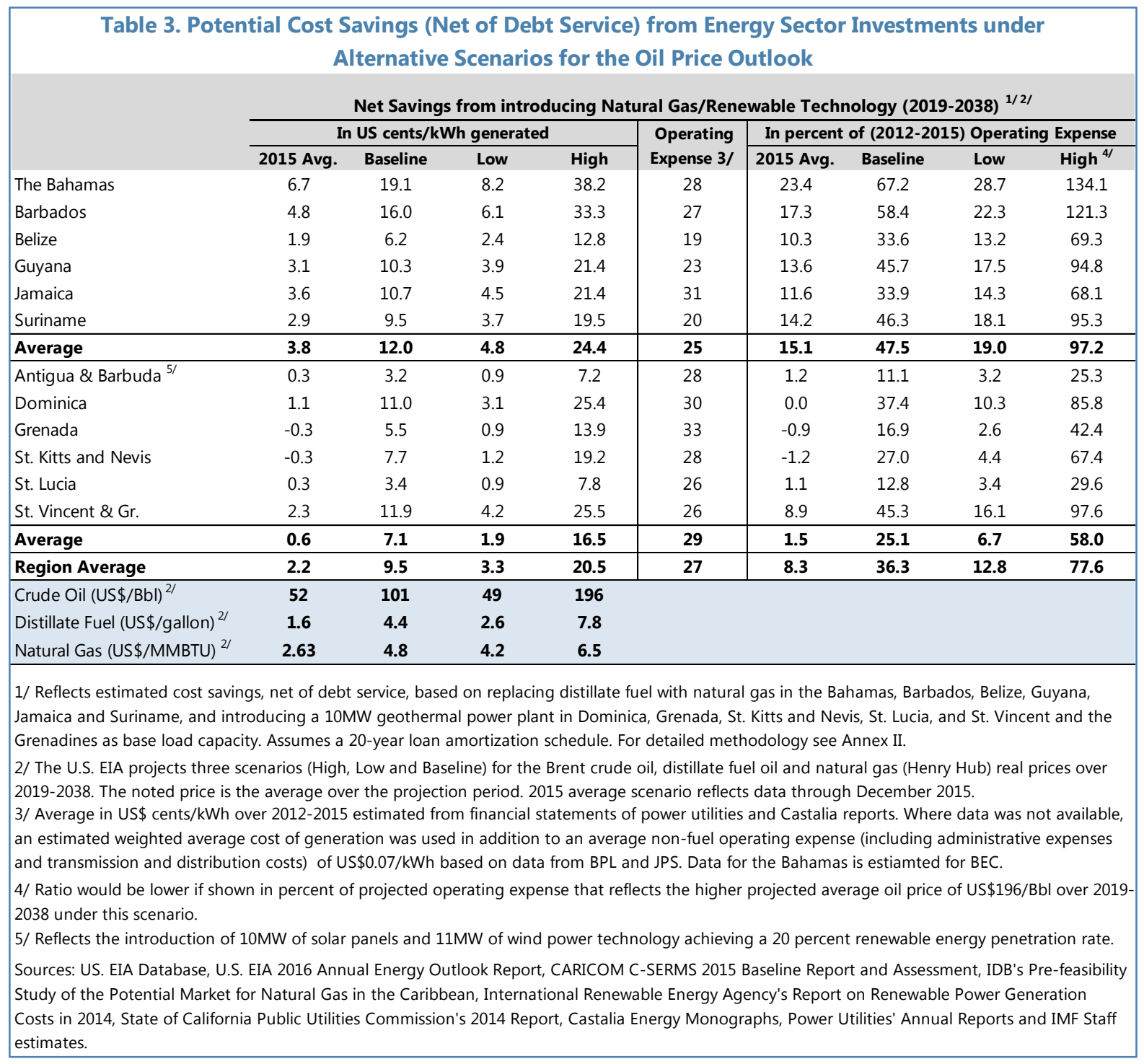

\section{Private sector financing of energy investments would have an additional favorable impact on public debt sustainability, to the extent that private investors share cost savings with the broader economy. Sharing of cost savings by the private power}

${ }^{25}$ Estimates of energy investment needs in the Western Caribbean and Barbados include the cost of converting existing plants run by fuel oil to natural gas-fired facilities.

${ }^{26}$ At 2015 fuel oil prices (the '2015 average' scenario), renewable energy introduction in the ECCU, including geothermal power, appears to provide limited to no cost savings under given financing and generation cost assumptions, while introducing natural gas would seem viable mainly because of the significant drop in natural gas prices since early 2015 . 
operator in a manner that reduces the economy's energy bill should generate the same growth dividends as public financing of the project, without the corresponding increase in the public debt burden. The exercise below depicts the assumptions for the public and private financing scenarios for each of the selected Caribbean economies. ${ }^{27}$

- Scenario 1: the public sector finances 100 percent of the investment in energy infrastructure. Reflecting the requirement that the projects eventually be self-financing, the scenario includes a projected improvement in the public sector primary balance to cover the debt service over the life of the loan, recouped from the projects' cost savings, consistent with a 20 -year cost recovery schedule for all investments. ${ }^{28}$ The impact on debt sustainability is modeled through 2030. Staff estimates of the fiscal stance and growth outlook in 2020 are held constant for subsequent years. ${ }^{29}$ Improvements in output growth from both the investment impact and the projected efficiency gains are incorporated into the growth outlook for this scenario (and the one below).

- Scenario 2: the private sector undertakes 80 percent of the investment. This scenario assumes that a private sector partner will finance the bulk of the infrastructure projects, particularly those that lend themselves to a private-public partnership type of set-up, like the development of renewable or natural gas-fired power plants. In such cases, the public sector would still need to make a financial contribution, often in the form of an equity tranche in the project's capital structure, as well as undertake some level of infrastructure investment, for instance in grid interconnection. The growth impact of the energy investments and the efficiency gains are the same as in Scenario 1. The public sector share of the investment is financed under the same terms as in Scenario 1 and the public sector primary balance is improved to cover the associated debt service from its share of recouped cost savings (i.e. 20 percent). Figures 1 and 2 depict the impact on public debt trajectories (compared to baseline) of the 12 Caribbean countries under scenarios 1 and 2.

\section{B. Impact of Energy Investments on Public Debt Sustainability}

\section{Figures 1 and 2 depict the public debt trajectory of 12 Caribbean countries} under private and public sector financing options compared to a baseline scenario. While results differ by country, there are important general conclusions.

- Public energy investments of the size envisaged would not materially alter the longrun trajectory of public debt in most countries. Although making the investment through the public sector raised the public debt ratio for all countries over the medium term, the modeled cost recovery for debt service and the positive impact on growth (from both the investment impact and lower energy costs) offset this increase in the long run.

\footnotetext{
${ }^{27}$ Both scenarios assume a 50 to 60 percent pass-through of cost savings from efficiency gains to the economy.

${ }^{28}$ Annex I details staff's methodology for estimating energy investments cost savings for each country to ensure projects are self-financing over a 20-year horizon (2019-2038).

${ }^{29}$ For the debt dynamics modelled through 2030 for Antigua \& Barbuda and Jamaica, where adjustment needs are expected to ease, the projected central government primary balance was capped at 3.0 percent after 2020 .
} 
- Private sector financing of energy projects would moderately improve the debt-toGDP ratio compared to the baseline and public investment scenarios. The growth enhancement from improvements in energy efficiency yields a lower debt-to-GDP path compared to baseline in all countries in Scenario 2. This is, however, contingent on the private developer passing a share of the cost savings back into the economy, e.g., in tariff reductions to end-users. Retaining the bulk of the cost savings as returns on investmenti.e., limited transmission of benefits to the broader economy-would reduce projected growth dividends from the lower cost of energy, unless the savings were used in another growth-enhancing investment or activity. In this regard, Power Purchase Agreements with limited reductions in consumer tariff rates are unlikely to generate the anticipated improvements in cost competitiveness in Caribbean economies. ${ }^{30}$

- In this calibration, the improvement in the primary balance as the result of the cost savings (which are greater than the debt service) dominates debt dynamics. The growth impact of the investment itself is large when the investment represents a high share of GDP, like in Barbados and St. Vincent and the Grenadines.

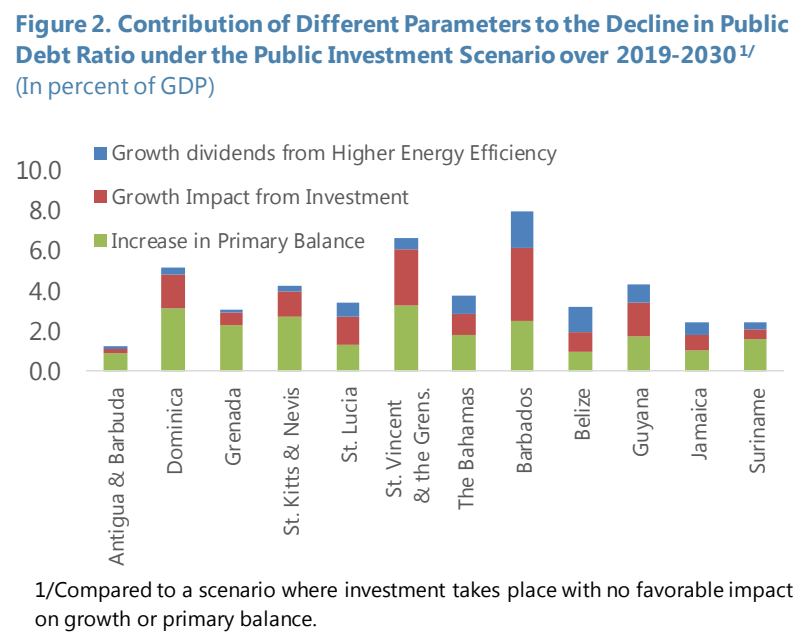

31. Countries fall into three categories of capacity to undertake these large-scale energy investments. See Figure 3 (ECCU countries) and Figure 4 (rest of the Caribbean).

- Countries with lower initial debt and sustainable debt dynamics can reap the benefit of reducing energy costs without weakening fiscal or debt sustainability. Under both baseline and public investment scenarios, the debt-to-GDP ratio in the Bahamas and St. Kitts \& Nevis is projected to remain below 70 percent through 2030 - the threshold for elevated debt sustainability risks in the IMF's Debt Sustainability Analysis Framework's for Market Access Countries. While public investments would thus be 'safe', these countries could still benefit from a private sector partnership in the projects. Guyana and St. Vincent \& the Grenadines have largely sustainable debt trajectories, but public financing of energy investments would keep the debt-to-GDP ratio above the 70 percent threshold till 2021 in Guyana and 2023 in St. Vincent \& the Grenadines (though the latter would reach the ECCU's 60 percent target by 2026). Finally, while Suriname's debt trajectory is projected to rise, its low initial public debt of 37 percent in 2015 could permit it to sustain the estimated 7.5 percent of GDP of energy investments over the medium term, particularly if the investment enables the country to eliminate energy subsidies estimated at 2.7 percent of GDP in 2013.

\footnotetext{
${ }^{30}$ Although the balance of payments would still benefit from a lower import bill for expensive fuel oil.
} 
- Countries with high public debt, and unsustainable debt dynamics, are not wellpositioned to scale up investment using public sector financing. Countries like Dominica and St. Lucia have a high probability of debt distress, given their high debt to GDP ratio and unsustainable debt trajectories. In Barbados, the public debt ratio is projected to remain above 100 percent till 2026 if energy sector investments are financed through public resources. ${ }^{31}$ Hence, in these countries, getting the private sector to undertake the bulk of the investments would ease financing constraints imposed by the need to avoid increasing public debt, and would also provide risk sharing-which could be particularly critical when the renewable resource potential remains uncertain or the energy market outlook is highly uncertain. The favorable impact on the debt trajectory from the better growth outlook would help improve debt sustainability. ${ }^{32}$

- Countries in an adjustment process to reduce public debt to sustainable levels could choose to finance high-yielding investments, as long as the economy can demonstrate strong structural preconditions. Preconditions would need to include high returns on public capital, high public investment efficiency and high collection rates. In Jamaica, energy investments, estimated at 6.2 percent of GDP, do not materially alter the debt path but could impose additional strain on fiscal resources if projected cost savings fall short of the cost of financing, particularly if financing terms are unfavorable or crowd out other investments. In countries where commercial losses are high or the power utility has low collection rates, transition problems could emerge if the costs of financing cannot be covered without fiscal adjustment. This could aggravate fiscal challenges if the baseline required fiscal adjustment is already high, as in Antigua \& Barbuda, Grenada, or Jamaica.

\footnotetext{
${ }^{31}$ Barbados' public sector debt ratio is being revised to include debt of state-owned enterprises.

32 However, as discussed below, prudent management of private sector contracts and power purchase agreements are necessary to limit any potential contingent liabilities to the fiscal sector.
} 


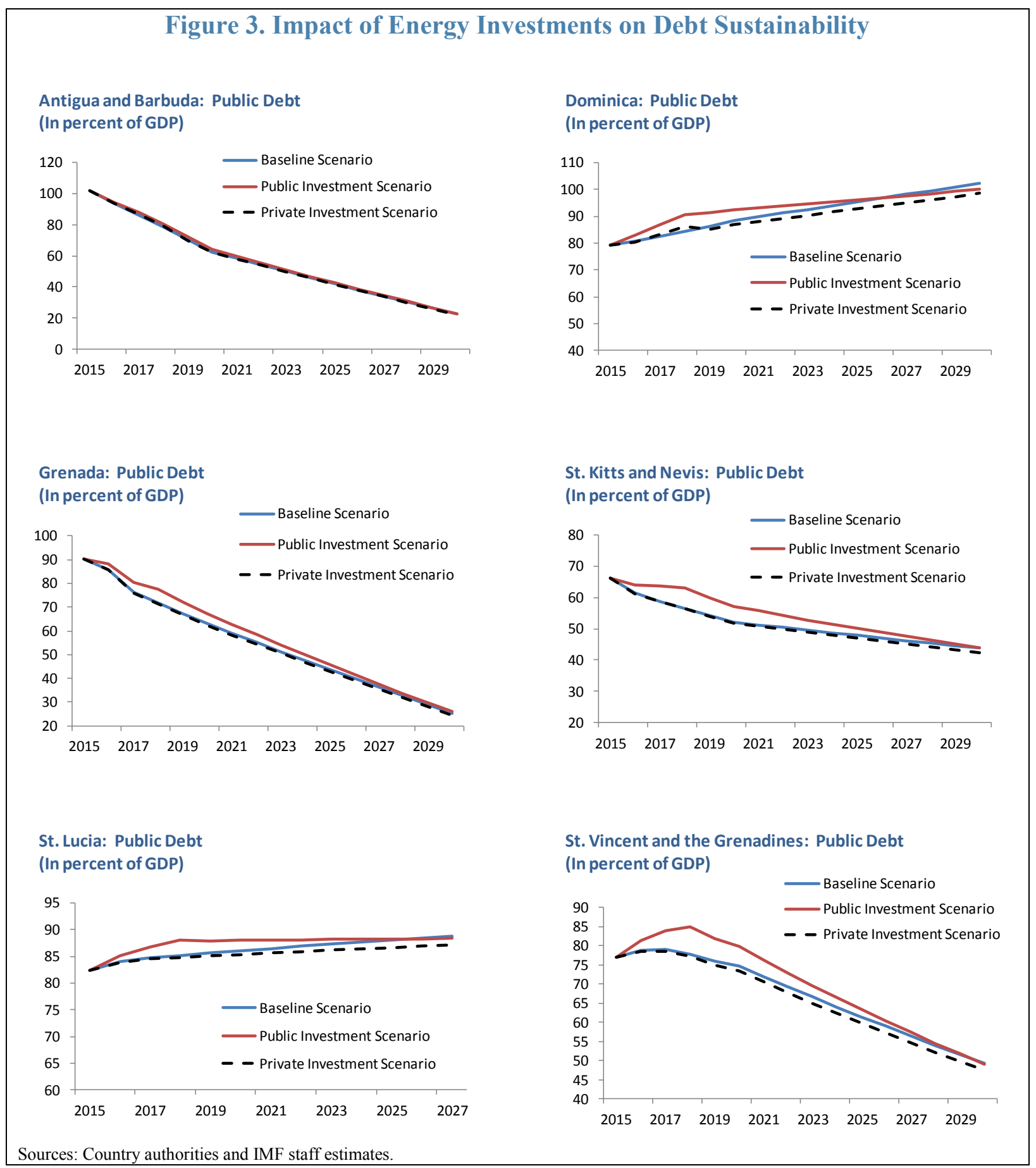

\section{CInternational Monetary Fund. Not for Redistribution}




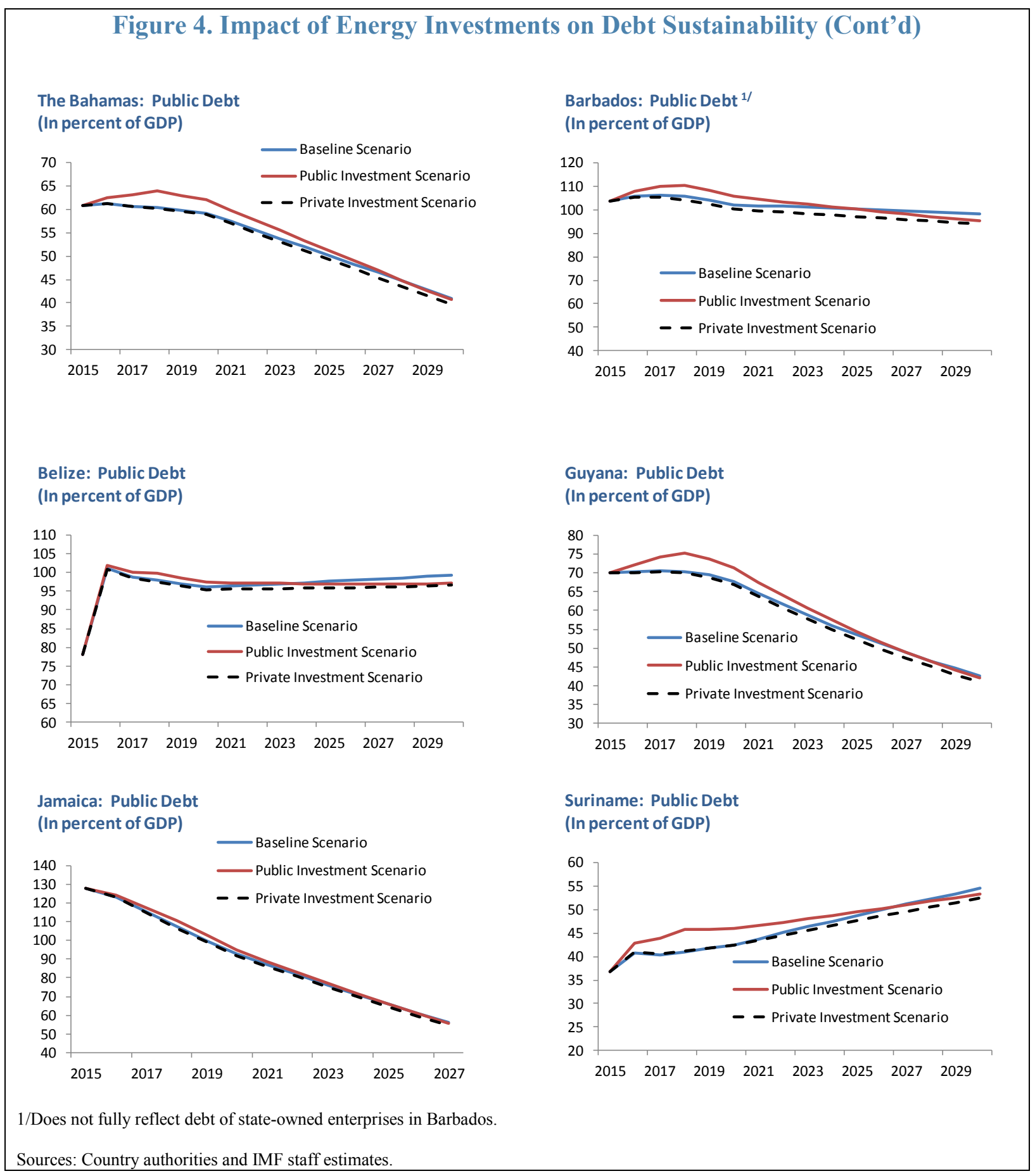

CInternational Monetary Fund. Not for Redistribution 


\section{Conclusion}

32. Small countries share the current global interest in scaling-up public investment but are concerned about the impact on fiscal and debt sustainability. To assess this impact more accurately, macro-frameworks that feed into the DSA framework would benefit from amendments to take into account the effects of macro-critical public investment projects, particularly for countries in a high debt-low growth trap. A comprehensive analysis should internalize the link between investment spending and future economic growth by weighing the expected medium and long-run growth dividends of the investment against the front-loaded increases in the public debt burden. Also, the fiscal projections that underpin the DSA should incorporate potential revenue streams or fiscal savings from public investment projects that charge user fees and/or generate significant cost savings to the public sectorsince these can make a project effectively self-financing.

33. Where projects are large enough to be macro-critical, bottom-up estimates of their impact should be taken into account in the macro-framework. The approach followed in this paper requires the estimation of only three key parameters: the growth impact of the project, the projected cost of financing it, and any impact on the public sector primary balance (say, earnings from user fees). The approach is most useful when a project has a high growth impact, low risk of private sector crowding out and a fairly guaranteed revenue stream. While the approach lacks the rigor of micro-founded DGE models, it is easier to integrate with policy analysis for countries with complex budgetary frameworks or fiscal consolidation.

34. More elaborate macro-modeling, of the DIG-model type, would be superior when investment scaling-up spans multiple sectors or provides public goods not amenable to cost recovery. The impact of cross-sectoral investment programs which aim to close large infrastructure gaps in public goods (perhaps the road transport network, healthcare, and basic public utilities) would be impractical to capture via this bottom-up approach - particularly when the projects do not generate distinct revenue streams or cost savings. Moreover, in such cases, growth projections would need to control for possible absorptive capacity constraints and declining marginal productivity of capital in the face of rapid accumulation of public capital; in such case, there would be no substitute for a comprehensive macroeconomic model like the DIG.

35. Energy investments in the Caribbean are an example where public investment projects could generate tangible cost savings to both cover financing costs and support long-run growth. A sustained reduction in the energy bill would deliver measurable longrun competitiveness and growth benefits, with favorable impact on public debt sustainability across most Caribbean economies. The estimated impact on long-run GDP following the pass-through of cost savings, net of debt service, yields a more favorable debt trajectory than the baseline in all Caribbean countries. The path remains sensitive to the overall cost of financing, the extent of the estimated growth impact, and projected changes in the relative cost of alternative energy sources to fuel oil.

36. For public financing of energy investments to be feasible, the baseline debt trajectory needs to be sustainable. Although the public debt trajectory under the 
investment scenario converges with the baseline on or before 2030 for all countries in the sample, countries where fiscal vulnerabilities remain acute, like Antigua \& Barbuda, Dominica and St. Lucia, are not well-positioned to finance investments through public resources, since these might derail necessary fiscal adjustment efforts and increase risks of debt distress over the medium term. Even if the debt trajectory is not explosive, relying entirely on public investment financing in such highly indebted states would increase vulnerability to large macro shocks, including natural disasters, by reducing available fiscal space and capacity to borrow. Hence, securing private sector financing of energy investments, where possible, would significantly improve the public debt path over the long run through reducing the initial rise in public debt load while retaining the long-run growthenhancing impact, provided that a significant share of the cost savings is reinjected into the economy - for instance, passed on to consumers in the form of lower electricity tariffs.

\section{A strong public investment management framework is a prerequisite for} favorable spillovers from the investment project to materialize. Countries that have a poor track record in executing public investment projects should first invest in strengthening their public financial management practices and public investment framework before undertaking large public investment projects. This is to ensure high public investment efficiency and reduce risks of cost overruns and financing shortfalls. Additional measures may be needed to safeguard the project's payoff, including outsourcing management of the project to the private sector and issuing regulations to protect the project's revenue stream from policy interference, to preclude shortfalls in revenue collections and future contingent liabilities to the public sector.

38. Transition problems from scaling-up public investment can be reduced by proper design of the financing transaction. Generally, projects that can generate a sufficient revenue stream through user fees to cover their financing cost are less likely to require distortionary fiscal adjustment and related transition problems. In particular, risks are lower when the cash flow needed to service the related debt matches the income stream of the project. Concessional external financing is the most favorable financing scenario, but is often not feasible in middle-and higher-income countries. Financing high-yielding public investment projects domestically may not crowd out domestic consumption and investment if surplus liquidity can be mobilized through appropriate long-term financing instruments. Absent these conditions, long-term external funding from multilateral development institutions is likely to be the best financing route to ensure a stable cost of finance and limit adverse financing pressures on the public sector in the event of unexpected shocks. 


\section{REFERENCES}

Bailey J. and N. Janson, 2013, "Pre-Feasibility Study of the Potential Market for Natural Gas as a Fuel for Power Generation in the Caribbean, Inter-American Development Bank.

Berg, A., R, Portillo, S.-C. Yang, and L.-F. Zanna, 2013, "Public Investment in ResourceAbundant Developing Countries,” IMF Economic Review, vol. 61(1), pp. 92-129.

Buffie, E., A. Berg, C. Pattillo, R. Portillo and L. Zanna, 2012,” Public Investment, Growth, and Debt Sustainability: Putting Together the Pieces," IMF Working Paper 12/144.

Cabezon, E. et al., "Enhancing Macroeconomic Resilience to Natural Disasters and Climate Change in the Small States of the Pacific," IMF Working Paper 15/125.

Dabla-Norris et al., 2011, "Investing in Public Investment: An Index of Public Investment Efficiency,” IMF Working Paper 11/37.

Ehlers, T., 2014, “Understanding the Challenges of Infrastructure Finance," Bank of International Settlements, Working Paper no. 454.

Garcia, J. et al., "Fiscal Multipliers in the ECCU," IMF Working Paper 13/117.

Giraud, G. and Z. Kahraman, 2014, "How Dependent is Growth from Primary Energy?

Output Energy Elasticity in 50 Countries (1970-2011)”, Centre d'economie de la Sorbonne, Paris.

Inter-American Development Bank, 2013, Energy Matrix Country Briefings. Washington, DC.

International Monetary Fund (IMF), 2013a, "Staff Guidance Note for Public Debt Sustainability Analysis in Market-Access Countries," Washington, DC.

International Monetary Fund (IMF), 2013b, "Staff Guidance Note on the Application of the Joint Bank-Fund Debt Sustainability Framework for Low-Income Countries," Washington, DC.

International Monetary Fund (IMF), 2015, "Making Public Investment More Efficient," Washington, DC.

International Renewable Energy Agency (IRENA), 2015, "Renewable Power Generation Costs in 2014," Bonn, Germany.

Masih, A. and R. Masih, 1996, "Energy Consumption and Real Income Temporal Causality, Results for a Multi-Country Study Based On Co-integration And Error-Correction Techniques.” Energy Economics 18, 165-183. 
McIntyre, A. et al., 2016, “Caribbean Energy: Macro-related Challenges,” IMF Working Paper 16/53.

Melina, G., S-C. Yang, L-F Zanna, 2014, “Debt Sustainability, Public Investment, and Natural Resources in Developing Countries: the DIGNAR Model". IMF Working Paper $14 / 50$.

Mu, Y., 2012, "Striking an Appropriate Balance Among Public Investment, Growth and Debt Sustainability in Cape Verde," IMF Working Paper 12/280.

Ochs, A. et al., 2015, Caribbean Sustainable Energy Roadmap and Strategy (C-SERMS): Baseline Report and Assessment. Worldwatch Institute. Washington, DC.

Pesaran, Shin \& Smith, 1998, Energy Demand in Asian Developing Economies, Oxford University Press, Oxford.

Petersen, S.L., 2002, "Micro Econometric Modeling of Household Energy Use: Testing for dependence between Demand for Electricity and Natural Gas.” Energy Journal, 23, 57-83.

Pritchett, L., 2000, “The Tyranny of Concepts: CUDIE (Cumulated, Depreciated, Investment Effort) is Not Capital," Journal of Economic Growth vol. 5, 361-384.

Stern and Kander, 2012, "The Role of Energy in the Industrial Revolution and Modern Economic Growth", The Energy Journal, 2012, vol. 33, issue no. 3.

Warner, Andrew M., 2014, "Public Investment as an Engine of Growth,” IMF Working Paper 14/148.

Wyplosz, C., 2007, "Debt Sustainability Assessment: The IMF Approach and Alternatives," HEI Working Paper, No. 03/2007, Graduate Institute of International Studies, Geneva. 


\title{
Annex I. Methodologies for Assessing Potential Cost Savings from INTRODUCING NATURAL GAS AND RENEWABLE ENERGY TECHNOLOGIES IN THE CARIBBEAN
}

\begin{abstract}
This Annex explains in more detail how potential cost savings from proposed investments in Caribbean countries were estimated. These estimations are key to i) determining whether projects are likely to be self-financing in the long-run; and ii) assessing the likely growth impact of the investments based on the magnitude of the potential efficiency gains from the new technologies, if the bulk of cost savings are passed on to end-users.
\end{abstract}

For energy investments to be economically viable, new technologies need to generate electricity for less than costs under the existing technology. This assessment is typically done through comparing the Levelized Cost of Electricity (LCOE) of each technology and estimating the potential cost savings over a given horizon. ${ }^{1}$ IDB estimates have provided cost estimates of potential energy investments in each country. Natural gas is considered viable in the Western Caribbean countries (the Bahamas, Belize, Guyana, Jamaica, and Suriname) and Barbados. Owing to the lack of sufficient economies of scale in Eastern Caribbean countries, natural gas is not considered an optimal option, particularly given the potential for geothermal development in most countries. The comparison is based on broadbrush assumptions and is not meant to replace detailed technical and financial evaluation of proposed projects. Projects are assumed to be financed through a 20-year loan at 5 percent interest rate with a 3-year grace period. New power plants are expected to be operational by 2019 and cost savings are calculated through 2038, consistent with a 20 -year cost recovery schedule. ${ }^{2}$

\section{A. Estimating Savings from Introducing Natural Gas}

Cost savings from introducing natural gas will ultimately depend on the price differential between distillate fuel oil and natural gas over a given horizon. The IDB provided specific cost estimates of i) building re-gasification facilities at port terminals to receive LNG; ii) converting existing installed capacity run by fuel oil to natural gas-fired stations; and iii) building additional capacity through 2023 to meet growth in electricity

\footnotetext{
1 LCOE represents the per-kWh cost of building and operating a power plant over an assumed financial life and duty cycle. Key inputs to calculating LCOE include capital costs, fuel costs, fixed and variable operations and maintenance $(\mathrm{O} \& \mathrm{M})$ costs, financing costs, and an assumed utilization rate for each plant type.

${ }^{2}$ Cost savings have also been calculated over a ten-year horizon (2019-2030) to ensure that the investment generates sufficient savings to cover for debt service in the early life of the project and does not lead to fiscal adjustment in the early years if the benefits are too back-loaded.
} 
demand. Table A1.1 shows the cost of converting existing capacity to natural gas-fired plants in addition to the size and cost of new natural gas capacity.

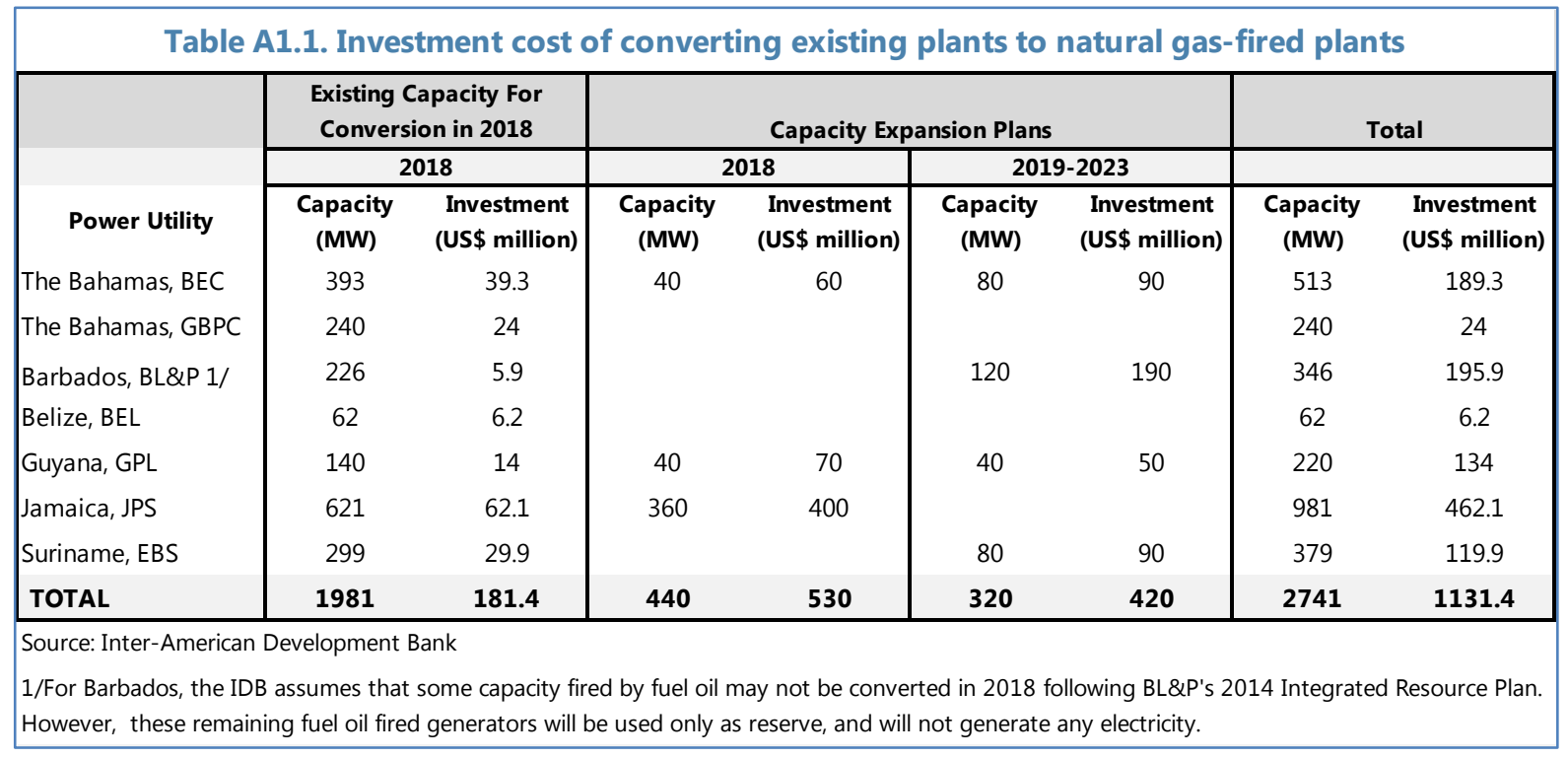

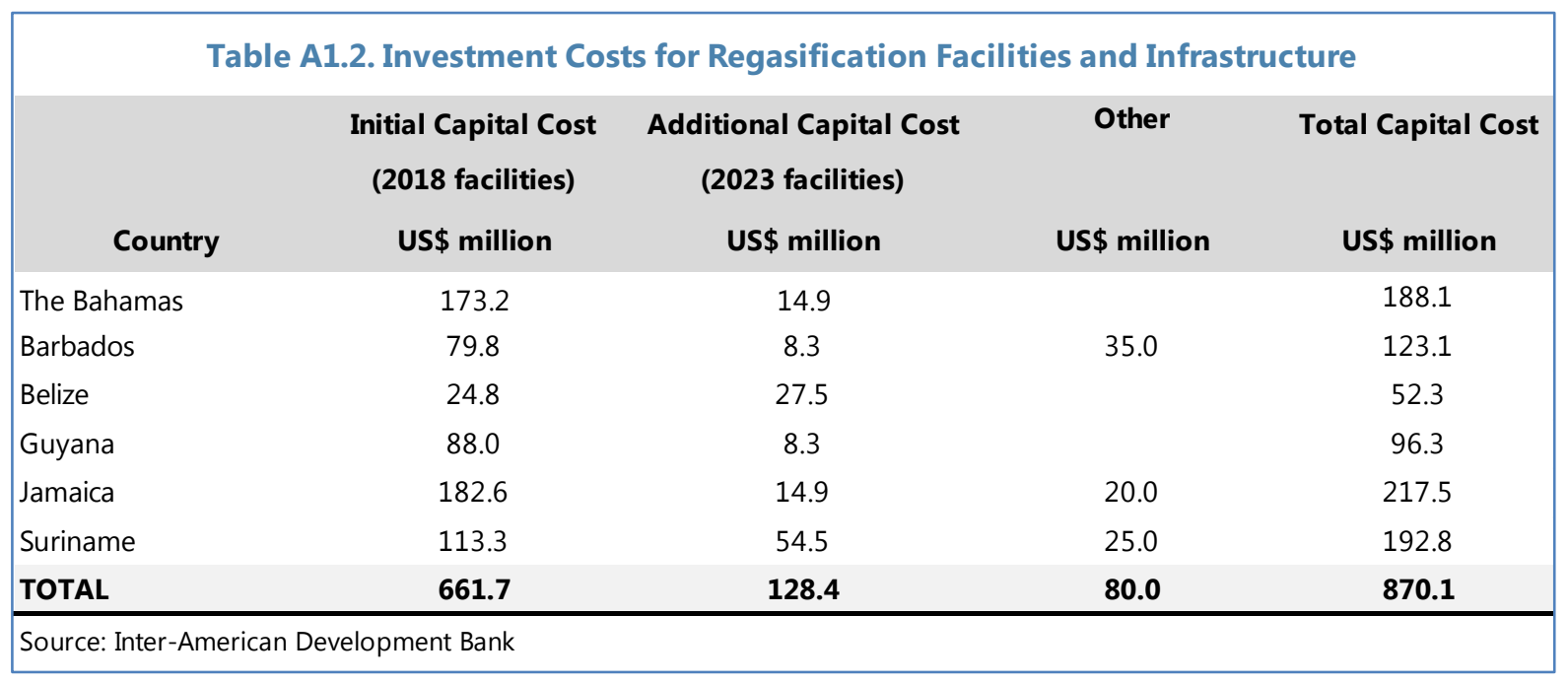

Because the power stations are expected to come on stream starting in 2018 with additional expansion in capacity coming in 2023, savings need to be based on the magnitude of net generation over a forecast horizon. The following methodology has been used to arrive at these potential cost savings from replacing expensive fuel oil with natural gas:

1. Using data from the U.S. EIA database for net generation of electricity per country, the growth of total annual net generation of electricity in GWh was projected through 2038 (a 20-year horizon starting in 2019). This is guided by growth rates in recent years as well as projections of growth in peak load for each country from Worldwatch Institute presented in the Caribbean Sustainable Energy Roadmap and Strategy (C-SERMS) 
Baseline Report and Assessment. The projections were also bound by the following constraints:

a. Net generation remains within planned capacity expansions. For each year, net annual generation of electricity could not exceed what could be actually produced using the available installed capacity for that year adjusted with the capacity factor for each technology in the generation mix of each country. ${ }^{3}$

b. In Countries where the IDB did not cost expansions in installed capacity (e.g. Belize), net generation projections only reflect the maximum capacity of existing power plants through 2038. Belize currently imports 40 percent of its generation from Mexico at an estimated price of US $\$ 0.12 / \mathrm{kWh} .^{4}$ This scenario assumes that additional growth in demand beyond that assumed in this exercise is covered by further electricity imports.

\section{The amount of net generation expected to come from conventional sources was} estimated after accounting for existing renewable technologies currently in place. These include the large hydroelectric power capacity in Belize and Suriname and biomass facilities in Belize and Guyana. They also include the small solar power capacity in each country based on most recent available data from Worldwatch Institute presented in CSERMS Baseline Report and Assessment.

3. Purchases of electricity by the power utility from Independent Power Producers (IPPs) were excluded to arrive at net generation by the utility alone. In Jamaica, about 40 percent of the electricity is currently purchased from IPPs. ${ }^{5}$

4. The cost of natural gas fuel per $\mathbf{k W h}$ was estimated by updating the results of the IDB's Pre-feasibility Study for the Potential Market for Natural Gas in the Caribbean released in December 2013. The benchmark natural gas price in this study was the Henry Hub index and the IDB used US\$4.00/MMBTU as a base case. The price was updated for various pricing scenarios, including the 2015 average price and projected average price of natural gas over 2019-2030 using the 2015 U.S. EIA Energy Market Outlook Report. The estimated average LNG transportation cost from the U.S Sabine Pass supply point used in

\footnotetext{
3 The net capacity factor of a power plant is the ratio of its actual output over a period of time, to its potential output if it were possible for it to operate at full nameplate capacity continuously over time. For renewable energy technologies this reflects the variable availability of the fuel (i.e. sunlight, wind or water). While conventional fossil-fuel based power plants have high capacity factors in excess of 80 percent, Solar PV panels capacity factor may be as low as 25 percent. Average capacity factor for each technology is sourced from U.S. EIA monthly data.

${ }^{4}$ Based on recent information from the Belize authorities.

${ }^{5}$ If IPPs are expected to run their facilities using natural gas, their generation and installed capacities may be included but, for lack of data, this exercise excludes their generation from the calculation.
}

(continued...) 
the IDB study was preserved for each country and countries' cost of natural gas fuel per $\mathrm{kWh}$ was calculated by updating the price in each scenario.

5. Gross Savings per $\mathbf{k W h}$ were calculated by comparing the fuel cost per $\mathrm{kWh}$ generated using natural gas against the average fuel cost (per kWh) of distillate fuel oil in 2015 and under the different price projections of both natural gas and distillate fuel oil by the U.S. EIA through $2038 .{ }^{6}$ Gross savings in US\$ million are calculated by multiplying the savings (from the fuel replacement) per $\mathrm{kWh}$ by the projected net electric generation from natural gas-fired facilities.

6. The annual cost of debt service (in US\$ million) is then deducted based on a 20-year amortization schedule and the total investment cost for each country.

7. Net Savings, net of debt service, are then calculated and presented as a percent of estimated operating expense for each utility (per $\mathrm{kWh}$ ) to estimate potential gains in operating efficiency (see Table 3 in the main text).

\section{B. Estimating Savings from Introducing Geothermal Power in the ECCU}

1. IDB cost estimates shown in Table A1.3 are used for geothermal plant development in the ECCU. The cost of a 10MW geothermal plant is estimated at US\$45 million for all countries but some countries are more advanced than others in the initial testing and drilling phases. Completed phases are discounted from the total cost of the project.

\begin{tabular}{|c|c|c|c|c|c|c|}
\hline \multicolumn{7}{|c|}{$\begin{array}{l}\text { Table A1.3. Estimated Costs to Develop a 10MW Geothermal Power Plant by Stage } \\
\text { (in US\$ millions) }\end{array}$} \\
\hline \multirow[b]{2}{*}{ Country } & \multirow{2}{*}{\begin{tabular}{c|}
$\begin{array}{c}\text { Stage 1a: } \\
\text { Pre-Investment }\end{array}$ \\
(Studies)
\end{tabular}} & \multirow{2}{*}{\begin{tabular}{|c|} 
Stage 1b: \\
Pre-investment 1/ \\
$\begin{array}{c}\text { (Slim hole } \\
\text { drillings) }\end{array}$ \\
\end{tabular}} & \multirow{2}{*}{$\begin{array}{c}\begin{array}{c}\text { Stage 2: } \\
\text { Exploration }\end{array} \\
\begin{array}{l}\text { (Full scale } \\
\text { drillings) }\end{array}\end{array}$} & \multicolumn{2}{|c|}{$\begin{array}{c}\text { Stage 3: Field } \\
\text { Development 2/ }\end{array}$} & \multirow[t]{2}{*}{ Total } \\
\hline & & & & $\begin{array}{l}\text { (Production/ } \\
\text { re-injection } \\
\text { wells) }\end{array}$ & (Plant Cost) & \\
\hline Dominica & (done) & (done) & (done) & 7 & 45 & 52 \\
\hline Grenada & 1.5 & 6 & 14 & 21 & 45 & 87.5 \\
\hline St. Lucia & 0.5 & 6 & 14 & 21 & 45 & 86.5 \\
\hline St. Kitts and Nevis & (done) & (done) & (done) & 21 & 45 & 66 \\
\hline St. Vincent \& Gr. & 1 & 6 & 14 & 21 & 45 & 87 \\
\hline Total & 3 & 18 & 42 & 91 & 225 & 379 \\
\hline \multicolumn{7}{|c|}{$\begin{array}{l}\text { 1/ Additional costs may be incurred to enable pre-investment activities in the development sites. } \\
\text { 2/ Does not include cost of sub-stations and transmission lines } \\
\text { Source: Inter-American Development Bank }\end{array}$} \\
\hline
\end{tabular}

2. The "current" weighted average cost of generation is determined based on the existing generation mix for each country to meet the average load. This is based on the installed capacities in each country, the per kWh cost of generation for each technology and the

\footnotetext{
${ }^{6}$ Average savings per kWh also materialize over shorter horizons over 2019- 2030 under a lower period average for the baseline oil price scenario.
} 
respective capacity factors for each technology. ${ }^{7}$ For Dominica and St. Vincent \& the Grenadines, the availability of hydroelectric power reduces the overall cost of generation.

3. The weighted average cost of generation of the "new generation mix" is then calculated. Geothermal power is used as base load in all scenarios. The assumed plant size is 10MW and fuel oil- fired plants are expected to pick up the remaining peak load after other renewable capacities are accounted for.

4. Generation costs for geothermal power plants are based on the 2014 California Public Utilities Commission Report using small-scale operating plants of comparable size to power plants planned for the Caribbean. A premium for small scale was still used for geothermal generation costs $(10$ cents/kWh vs. reported 7.3 cents $/ \mathrm{kWh})$. Hydroelectric generation costs are based on VINLEC data. (These are all-in costs, including operating and maintenance and equipment depreciation. This excludes any profit making and cost of capital typically included by private developers in geothermal prices quoted in Power Purchase Agreements). 8,9

5. Gross savings are calculated based on multiplying the reduction in the weighted average cost of generation after introducing geothermal and the amount of $\mathrm{kWh}$ generated for each country. This is done under alternative scenarios for distillate fuel oil price through 2030.

6. Net savings after debt service is then calculated based on individual amortization schedules and are shown both in US\$ cent $/ \mathrm{kWh}$ and in percent of average operating expense for each utility (see Table 3 in main text).

\section{Estimating Savings from the Announced 20 Percent Renewable Energy Target in Antigua \& Barbuda}

The IDB did not cost investments for Antigua \& Barbuda, which has no geothermal resource.

1. A mix of wind and solar PV panels is expected to achieve overall penetration of $20 \%$ of renewables by 2020, according to the authorities' announced plans.

2. The authorities have announced plans to develop 10 MW of solar PV panels, of which a $2 \mathrm{MW}$ solar farm is currently operational near the airport. The estimated cost for this is US\$20.5 million. They expect to achieve the target by introducing a wind farm. $\mathbf{A}$ minimum of $11 \mathrm{MW}$ of wind power installed capacity is needed to reach 20 percent of

\footnotetext{
${ }^{7}$ Capacity factors are sourced from the U.S EIA database.

${ }^{8}$ This is backed by estimates for costs of generation for different renewable including solar and wind power from International Renewable Energy Agency (IRENA) report on Renewable Power Generation Costs in 2014.

${ }^{9}$ The cost of generation for conventional fuel oil-fired turbines includes an average of 4.4 cents/kWh of nonfuel costs of generation that cover operating and maintenance expenses and equipment depreciation in line with the IDB's estimates used in the Pre-Feasibility Study for the Potential of Natural Gas in the Caribbean.
}

(continued...) 
the mix. Cost estimates for wind power development from the International Renewable Energy Agency suggest an upfront capital cost of about US\$22 million for an $11 \mathrm{MW}$ wind farm. ${ }^{10}$

3. Savings are calculated based on the reduction in the weighted average cost of generation under different scenarios for the average price of distillate fuel oil, which is currently used for 99 percent of electric power generation in Antigua and Barbuda.

4. Net savings after debt service are then calculated and shown both in US\$ cent $/ \mathrm{kWh}$ and in percent of average operating expense for each utility (see Table 3 in main text).

${ }^{10}$ See IRENA’s "Renewable Power Generation Costs in 2014"; Section 4. 